\title{
Development of an Innovative and Sustainable Model for Integrating River Maintenance with Energy Production from Residual Biomass
}

\author{
Barbara Marchetti ${ }^{1}$ (D) , Francesco Corvaro ${ }^{2}$, Fabio Polonara ${ }^{3, *}$ and Mariella Leporini ${ }^{2}$ (D) \\ 1 Facoltà di Ingegneria, Università degli Studi eCampus, Novedrate 22060, Italy; \\ barbara.marchetti@uniecampus.it \\ 2 Dipartimento di Ingegneria Industriale, Università Politecnica delle Marche, Ancona 60131, Italy; \\ f.corvaro@univpm.it (F.C.); m.leporini@univpm.it (M.L.) \\ 3 Construction Technologies Institute, National Research Council (CNR), San Giuliano Milanese, \\ Milan 20098, Italy \\ * Correspondence: f.polonara@univpm.it
}

Received: 2 March 2018; Accepted: 11 April 2018; Published: 17 April 2018

\begin{abstract}
This study aims to develop an innovative model for managing territory maintenance in which the productive function is linked with the protective one and that integrates environmental and economic development aspects, combining the energetic valorization with an effective territory maintenance program. The strong innovation consists in the creation of an agro-energy environment chain based on the maintenance of river basins and small waterways made by single farmers or associations that will use residual biomass to produce electrical and thermal bio-energy. The maintenance activities include the control of aquatic weeds, grass cutting on river banks, and tree/bush management. If left unmanaged, they can block the flow of watercourses and increase the risk of flooding. The implementation of this virtuous model to the rivers maintenance aims to provide management and conservation means based on the territory characteristics. In fact, the new model has been applied to an existing site in the Marche region (Italy) located near a river characterized by a poor state of maintenance. A real commercial system for residual biomass exploitation was chosen, and both the technical and economic feasibility of the model implementation have been demonstrated.
\end{abstract}

Keywords: bio-energy; agro-energy; biomass; floods prevention; gasification; river maintenance; sustainability

\section{Introduction}

In the past few decades, increasing importance has being given to the difficult management of marginal areas and related environmental issues. The term "marginal areas" refers to all the public areas such as rivers, roads, and rail lines borders-the border areas of civil settlements.

The primary function of river maintenance, such as vegetation control and desilting (carried out by local government authorities), is to deliver particular standards of flood protection and land drainage service. Maintenance influences the relationship between flows and levels in the river and drainage system and affects the ability of the channel to retain flows of a given magnitude, thereby reducing the risk of flooding. According to Tabacchi et al. [1], stream channel and floodplain morphology are indeed governed by the volume and timing of discharge, the volume, timing and character of sediment delivery and transport, and the large-scale geological history and geomorphology of the drainage basin. $\mathrm{O}^{\prime}$ Connel et al. [2] presented a deep review of the UK land use and management practices over the past 50 years, establishing that there is a strong relationship between the increased surface runoff generation and local scale flooding and modern land-use management practices. 
The poor state of maintenance of these areas, or even the abandonment thereof, can be attributed to the lack of funds in the coffers of governments. The situation is made worse due to the absence of a genuine policy of integrated management of these areas, leading to sporadic interventions and adverse effects on environment and very high costs. This picture demonstrates that there is a need to adopt long-term risk management strategies grounded in an understanding of exposure to the flood hazard, characteristics and patterns of vulnerability, and the relationships between different stakeholders in the perception of flood risk [3].

Bad management of resources results in lack of policy for the retention of rainwater, which triggers hydro geological problems such as floods and landslides. These environmental disasters are reported as "emergencies" by the mass media, but this was not the case in the past because the presence of the farmer ensured the conservation of land and landscape. The past few years have experienced a disconnection between the farmer and the land, and this has led to a gradual abandonment of the territory maintenance. The reasons of this trend are

$>$ increased push toward mechanization that led to the elimination of hedgerows and field lines between cultivated areas;

$>$ wood is no longer used as a source of energy;

$>$ introduction of new regulations and constraints;

$>$ factors related to the economic livelihood of farms;

$>$ farmers have no economic interest in maintaining territories only for the benefit of the whole community.

An outstanding example of this behavior can be found in the maintenance of river beds. In the past, the farmer working with the river riparian system periodically watered, performed environmental engineering, and engaged in selective cutting of trees found in the "bed" to collect some wood to stay warm during the winter. Today, however, the maintenance of the rivers is not carried out annually but with a much lower frequency (maybe once in 10 years) and commissioned to building companies that perform a complete removal of the topsoil, causing hydro-geological problems such as erosion. Moreover, the residual biomass from maintenance is not recovered for energy use but is disposed as waste with a resulting increase of total maintenance costs.

In the last few years, several projects have been carried out about sustainable, profitable, and efficient rivers and territory maintenance [4]. An example is the experimental yard created by the "Comunità Montana of Camerino" along the Chienti river bed below the village of Pieve Torina (MC), which is typical of the general characteristics of hydraulic degradation. In this site, a system of river management, valid under hydraulic and environmental profiles, has been designed, but it does not provide a method for the valorization of the residual biomass obtained or guidelines and best practices for standardizing the maintenance approach. The present study, on the contrary, aims to develop a sustainable, replicable model for integrating river maintenance and energy production in any site characterized by hydro-geological risks.

In synthesis, the idea consists in the restoration of the riparian vegetation of the public demesnes, where missing, or where there is the need of reintegrate autochthon species and in the forest maintenance and energetic valorization of resulting biomass. The maintenance model will examine the river from different points of view: hydraulic, hydro-geologic, forest, flora and fauna, and landscape.

The maintenance objective includes

- maintaining flood barriers and pumping stations;

- clearing grills and removing obstructions from rivers;

- controlling aquatic weed within rivers;

- managing grass, trees and bushes on flood embankments;

- inspection and repair of flood defense structures. 
A positive consequence of the implementation of this virtuous model to river maintenance will be the increased usability of the river, which will generate sustainable rural tourism. In this way, in fact, it will be possible to create a connection between coastal tourism and the valley area of the water course bringing economic benefits. Moreover, the requalification and valorization of public demesnes areas will trigger a virtuous mechanism that will promote a new local economy based on the landscape and agriculture.

The entire system is developed around the farmer, who will be in charge of the river maintenance and will be the promoter of the wood-energy chain for electrical and thermal energy production from the residual biomass.

This innovative integrate management model can be implemented in all marginal areas such as small waterways, roads and rails borders, and other public demesnes areas. In the present paper, this model is implemented into a real site characterized by a very poor state of preservation with a significant degradation individuated near the Musone River (Marche, Italy).

\section{Literature Review}

The model presented in this study is characterized by the integration of different aspects related to river maintenance and by the involvement of the main stakeholder: local government, industries, farmers and farmers associations, and citizens. It has the aim of proposing a solution for flood mitigation at the local scale and improving river environments by exploiting natural resources such as residual biomass for energy production. Such an approach has not yet been proved in the literature and could be a key factor in overcoming the problem of high investments needed to increase renewable energy (RE) penetration in small- and medium-sized urban communities [5]. The environmental issue of river maintenance has been studied by many scientists from different points of view, and, in the past few years, the importance of integrating a broad range of competences has been outlined. For decades, evaluation projects on river maintenance and management were carried out by measuring only tangible streams of cost and benefits summarized in a cost-benefit analysis. Recently, environmental and social aspects have gotten more attention in the public decision-making process by means of multi-criteria analysis [6].

King et al. [7] described a holistic methodology, Downstream Response to Imposed Flow Transformation (DRIFT), for advising on environmental flows for rivers targeted for water-management activities. The methodology employs experienced scientists from several biophysical disciplines: hydrology, hydraulics, fluvial geomorphology, sedimentology, chemistry, botany, and zoology. Where there are subsistence users of the river, the following socio-economic disciplines are also employed: sociology, anthropology, water supply, public health, livestock health, and resource economics.

Many studies on river management addressed the issue of flooding risk estimation by trying to find the relationship between different factors mostly related to the loss of natural habitats that has proved to drive disasters that disrupt human lives and property [8], especially in developing nations, where the highest levels of biotic endemism are generally found [9].

Demonstrations of the relationships between the conservation of nature and benefits to human welfare provide the relevant perspective that is often necessary to convince people of the value of natural systems and encourage policy makers to include social and economic planning with technological approaches to water management. An improved approach to watershed and flood management proposed by [10] integrates watershed and land-use management in the highlands with land-use planning, engineering measures, flood preparedness, and emergency management in the affected lowlands while taking into account the social and economic needs of communities in both the highland, often source areas, and also the lowland flood-prone communities. This approach should be based on the best available scientific knowledge of the causes and the environmental, social, and economic impacts of floods and the environmental, social, and economic effects of engineering interventions. 
There are also many papers in the literature that focus on the energetic valorization aspects and address the production of energy from biomass from an environmental, economic, and social point of view [11-13] described the introduction of biomass utilization plants that was chosen as an effective tool to reduce environmental pollutants and substitution occurs between nitrogen monoxide and total nitrogen during the emission of nitrogen into the environment. The results imply that the promotion of biomass resource utilization can improve both the environment and economy, and policy making for water quality improvement should also take into account the effects on global warming of policy measures.

Zhang et al. [14] focused their research on a critical aspect related to the production of bioenergy from woody biomass: the identification of the optimal location for the facility. The location decision is especially important for woody biomass feedstock owing to the distributed nature of biomass and the significant costs associated with transportation. They presented a two-stage methodology to identify the best location based on multiple attributes. Stage I uses a Geographic Information System approach to identify feasible bioenergy facility locations. The approach employs county boundaries, a county-based pulpwood distribution, a population census, city and village distributions, and railroad and state/federal road transportation networks. In Stage II, the preferred location is selected using a total transportation cost model.

De Montis and Zoppi [15] addressed another important aspect: the social acceptance of biomass-based power plants and the resistance of local communities that makes planning for the development of such plants often very difficult. They investigated the level of social consensus on and support of the development of an energy plant based on the use of vegetal biomass in Central Sardinia, Italy. The method adopted is Contingent Valuation. Estimates of ex-ante household willingness-to-pay are implemented, as they are important indicators of the social endorsement for the project development. Implications concerning consensus/disagreement on innovative technologies for sustainable energy production are discussed as perspectives of future research.

The involvement of the local community as well as the main stakeholder is foreseen as a necessary step in the implementation of the proposed model. As demonstrated by Achterkamp and Vos [16] the stakeholders involvement serves two goals: to clarify the local criteria for sustainable outcomes, and to activate organizational practices according to these criteria. The replication of the model on a larger scale can attract the interest of many Italian industries that have been facing for several years now, a continuous increase of global competition that can be tackled only by a strong commitment to realize products characterized by a very high level of quality and performances that are in the same time environmental friendly [11].

\section{Methodology}

Starting from the need to develop an appropriate cycle of hydraulic-forestry maintenance of the riparian areas, a virtuous model for the integration of the hydro-geological risk mitigation with the energy production from biomass has been developed.

The structure of the model foreseen nine main phases, classified into two different groups: preparatory and realization.

The preparatory phases have the function to prepare the ground for developing and implementing the model by defining the procedure to request all the necessaries authorizations, comprehending a list of the documents to submit to the competent territory authorities (Phase P1: "Negotiation table and regulation assessment"), and by assessing the perception of the local population toward the projects aims and toward the proposed technology for energy production from residual biomass, the perception of advantages that the project will bring to the local territory from and economic, environmental, and social point of view, in order to avoid the "not in my backyard" reaction (Phase P2: "Benchmarking of project acceptance by the local community").

The realization phases represent the core of the model and have been divided in two main subgroups: model development and model implementation. The phases related to the model 
development are related to the design of the different means, tools, and structures needed for implementing a future project and for demonstrating its feasibility. During the model development, all the aspects and characteristics of the territory of interest are assessed, and an exhaustive picture of the entire ecosystem (also with the aim of avoid any negative impact on the natural environment), including its potentialities from an energetic point of view, is provided. This phase will produce a specific technical report in which will be described the territorial characteristics such as morphology and hydrography, geology, pedology, flora, fauna and vegetation, quantities and characteristics of available residual biomass, and relative pretreatment technologies (Phase R1: "Analysis of the characteristics of the selected territorial zone"). The detailed maintenance plan comprehensive of all the needed interventions (use of GPS-based systems to delineate the boundary between public and private owned land, calculation of the hydrological balance of the catchment area incident to size the optimal storage capacity of the drainage network; reopening and reprofiling of the river network sections in order to preserve water safety; identification of the potential vegetation that can be planted; design of reforestation, forest nursery production, planting, and subsequent management of forest areas close to river, depending on the various functions of potential vegetation (hydraulic, ecological, etc.), track creation for the forest maintenance), and of all the means and equipment involved must be elaborated (Phase R2: "Design of river maintenance plan"). The design of the energy generation system is executed by defining different aspects related to the gasification system selection and optimization, the design of all related components (e.g., the dryer, the filters, etc.), the selection of the cogeneration unit (engine of turbine), the design of the logistic supply chain, the design of the energy distribution network (Phase R3: "Design of the energy generation plant"). This phase foresees the development of a tool for the evaluation of the energy plant feasibility and convenience from both an economical (calculation of Pay Back Period or PBP, Internal Rate of Return or IRR, Net Present Value or NPV) and environmental (assessment of carbon balance and energy efficiency of the proposed project) point of view (Phase R4: "Business plan and environmental impact model").

At the end of the development phase it will be possible to proceed with the model implementation that will consist of three phases:

- the implementation of the river maintenance plan that must be carried out in the selected river stretch with the creation of the maintenance track and the residual biomass stacking (Phase R5: "Implementation of river maintenance plan on selected river stretch");

- the implementation of the plant and all its component as designed in Phase R3 that comprehend the preparation of the site by building all the necessary structures (concrete platform to support the plant, system coverage, etc.) and of the storage area for the biomass stacking, preparation, and pretreatments. Only after that the site and all relative structures and equipment are in place is it possible to proceed with the installation of the energy generation system and of all its components and of the energy distribution network (Phase R6: "Realization of energy plant for energy production and distribution");

- the last implementation phase involves the individuation of the minimum requirements for the system to follow and provides a working manual with system specifications, operating and maintenance procedures, performance guarantees, list of items supplied and user site layout requirements (Phase R7: "Plant operation and performances evaluation").

\section{Model Development}

The structure of the model developed is shown in Figure 1, and the main phases are described below. 


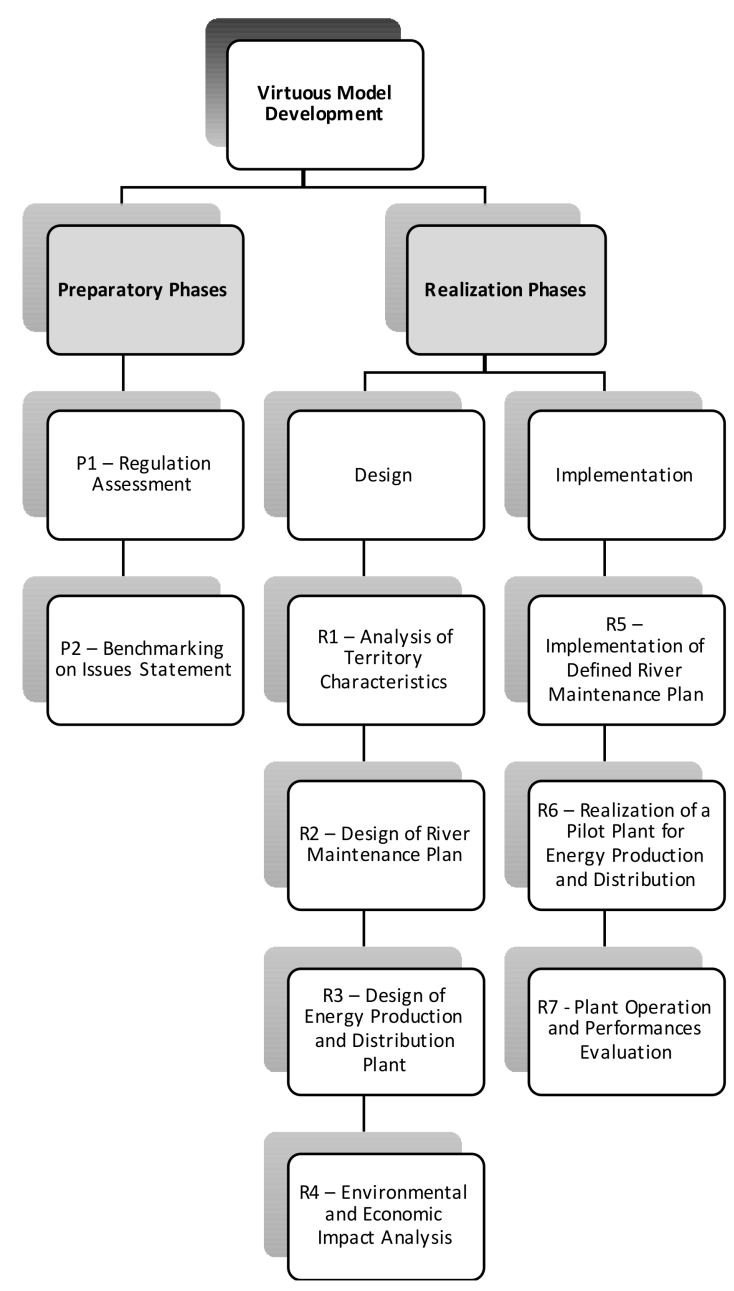

Figure 1. Model structure.

\subsection{Phase P1. Negotiation Table and Regulation Assessment}

This phase involves the production of a detailed overview of the current management of river maintenance, constraints and regulations related to maintenance interventions on river beds and banks.

In particular it is defined the procedure to request all the necessaries authorizations, comprehending a list of the documents to submit to the competent territory authorities.

During this phase, the following tasks must be performed:

- $\quad$ regulations assessment (PAI, PSR, PPAR, forest management plans, etc.);

- definition of jurisdiction areas for the local authorities involved in river maintenance;

- overview of previous cooperation agreements between local territory government and farmers;

- definition of model for land grant agreements between farmers representative and governmental bodies in charge of river management;

- definition of permits needed to implement the pilot plant;

- definition of procedure for permits request;

- definition of the protocol for green certificates and energy efficiency certificates request.

\subsection{Phase P2. Benchmarking on Issues Statement to Local Population}

An accurate survey must be realized at the local level through a specific questionnaire submitted to the population. The objective of the questionnaire is to identify and quantify the level of knowledge and acceptance toward the possibility of the bio-energy plant installation and in particular toward the 
proposed technology for energy production from residual biomass, the perception of advantages that the project will bring to the local territory from an economic, environmental, and social point of view.

The results of the benchmarking must be used for implementing effective communication and information actions at local level. The evaluation of the project acceptance by the local community enables us to gather and illustrate, through a statistical analysis, a wide range of information such as:

- level of knowledge of the local community toward the proposed energy production method based on biomass gasification;

- level of trust related to the impact of the plant on the environment and on the human health;

- advantages and disadvantages of the implementation model perceived by the population;

- knowledge of risks for the population, the environment, and the economy related to the state of river maintenance;

- population expectations related to environmental policy of local government bodies;

- population expectations related to the use of territory;

- $\quad$ overall perception of the project effectiveness.

The questionnaires must be administered, either in paper and digital format, to the largest possible number of residents. To facilitate the compilation and to reduce the risk of error in data management, the questionnaires must be designed as a set of closed questions. In particular, the questions follow an order that will not influence the subsequent responses, not require long response times, or at least, a thorough knowledge of the topics discussed and involve the citizen's attention thanks to a particular graphic setting.

\subsection{Phase R1. Analysis of the Characteristics of the Selected Territorial Zone}

The model developed, and that will be implemented in a power plant, has the characteristic to be applicable to other territorial areas and rivers. To assess the feasibility of such model, it is necessary to evaluate different aspects and characteristics of the territory of interest and to elaborate an exhaustive picture of the entire ecosystem, including its potentialities from an energetic point of view.

This phase is focused on the evaluation and consequent elaboration of a specific technical report in which must be analyzed territory characteristics such as morphology and hydrography, geology, pedology, flora, fauna and vegetation, quantities and characteristics of available residual biomass, and relative pretreatment technologies.

The phase $\mathrm{R} 1$ is organized in five main tasks illustrated in Table 1.

Table 1. Task of the phase R1.

\begin{tabular}{ll}
\hline \multicolumn{1}{c}{ Task Name } & \multicolumn{1}{c}{ Task Description } \\
\hline & $\begin{array}{l}\text { The task includes the assessment of geographical limits, morphology and } \\
\text { hydrography, geology, climate, pedology aspects, floral and botanic-vegetation } \\
\text { aspects, wildlife aspects. The main aim is to draw up a complete cognitive } \\
\text { framework of the interested river or the river portion. }\end{array}$ \\
R1.1 & $\begin{array}{l}\text { This task includes the collection and the analysis of the historical data on rain } \\
\text { events to evaluate the maximum flood rate, expected (with a return time } \\
\text { characteristics of the territory } \\
\text { object of the planning and of } \\
\text { the surrounding area }\end{array}$ \\
& $\begin{array}{l}\text { calculated in two hundred years) in the examined river stretch. From the flood } \\
\text { rate, the watercourse sections will be verified, and the criticalities underlined. It } \\
\text { will be also evaluated in which stretches the replanting of tree species could }\end{array}$ \\
& $\begin{array}{l}\text { produce positive effects from a hydraulic point of view (stabilization of } \\
\text { riverbanks, decreasing of velocity) and which interventions on the local } \\
\text { vegetation could prevent the effects of the water flooding. }\end{array}$ \\
& $\begin{array}{l}\text { In this task, the juridical binding bases will be addressed in order to provide the } \\
\text { instruments for a correct evaluation of the typology of interventions to } \\
\text { implement in the different area. Regulations related to landscape-environment, } \\
\text { Regulatory framework }\end{array}$ \\
& $\begin{array}{l}\text { forest, soil protection and water demesne management will be taken into } \\
\text { account. }\end{array}$ \\
\hline
\end{tabular}


Table 1. Cont.

\begin{tabular}{|c|c|}
\hline Task Name & Task Description \\
\hline $\begin{array}{l}\text { R1.3 } \\
\text { Plan characteristics and } \\
\text { working methods }\end{array}$ & $\begin{array}{l}\text { In this task, the following scripts will be produced: cartography, register of } \\
\text { management units, record of interventions, dendro-crono-auxometric surveys } \\
\text { (in field), structural and typological analysis of populations, overview and } \\
\text { justification of the assessment methods adopted. For each Unit of Soil (UoS), } \\
\text { deriving from the partition of the wooded topsoil by homogeneous culture } \\
\text { units, it will have to be performed a number of sampling area congruous with } \\
\text { the total surface of the analyzed portion (at least } 1 \text { sample each } 2 \text { ha). In } \\
\text { particular, the dendro-crono-auxometric surveys will have to be performed } \\
\text { collecting the following parameters: number of tree divided by wood species; } \\
\text { diameters distribution curve, detailed description of each Unit of Soil (UoS). } \\
\text { The UoS characterization will be used to detect reforestation areas and to define } \\
\text { the essential characteristics of the reforestation plan. }\end{array}$ \\
\hline $\begin{array}{l}\text { R1.4 } \\
\text { Description of the Unit of Soil } \\
\text { (UoS) }\end{array}$ & $\begin{array}{l}\text { In this task, it will be reported the description of the forest UoS (copses, } \\
\text { transitory high timber, high timber, description and settlement of young } \\
\text { species, gaps and clearings, vegetation and plant health state), other categories } \\
\text { of use of soil and relative UoS (newly formed woods, erosions areas, wood } \\
\text { arboriculture plants, active, inactive or dismissed pits, building and pertinences, } \\
\text { main and secondary roads, etc.). }\end{array}$ \\
\hline $\begin{array}{l}\text { R1.5 } \\
\text { Energetic potential evaluation }\end{array}$ & $\begin{array}{l}\text { From the elaboration of the data coming from the territory and forest } \\
\text { evaluation, the bio-energy potential of the selected area must be calculated } \\
\text { (biomass available per linear km of river); other than this main source of } \\
\text { biomass, it will also be evaluated the possibility of integration with waste from } \\
\text { cultivated field in the area, and from public green maintenance (road boards, } \\
\text { parks, forest and other public areas) in order to address also the important } \\
\text { issue, constantly faced by public governments of managing waste from } \\
\text { maintenance of public green areas. } \\
\text { Each type of biomass has its own specific properties which determines its } \\
\text { performance as a fuel in gasification plants. The most important properties that } \\
\text { will be evaluated for each identified and available type of biomass are the } \\
\text { moisture content of biomass, the ash content and ash composition, the } \\
\text { elemental composition of the fuel, the bulk density and morphology of biomass } \\
\text { and the volatile matter content. }\end{array}$ \\
\hline
\end{tabular}

\subsection{Phase R2. Design of River Maintenance Plan}

The planning of the whole maintenance and requalification project will be based on the analysis of the territory and its different functional aspects, such as the potential vegetation and its functionalities and the possibility of implementing a suitable mechanized forestry maintenance system.

River maintenance covers cutting of vegetation, dredging, bank and tree clearance, and repairs to banks and structures. These activities influence all aspects of river management including flood defense, morphology, conservation, recreation and fisheries, and it involves the application of a large number of regulations and the interaction of different authorities that are often difficult to integrate and unify.

To plan an effective and equitable management of rivers at the catchment or basin level, all water-related activities should be considered, including water availability, demand, and use; water quantity (high and low flows) and the quality; groundwater, habitats, and ecology; interactions with soils and sediments; land use; agricultural and urban runoff (quantity and quality); ecological status of water bodies; and the social and economic development.

The design of the maintenance plan is described in Table 2. 
Table 2. Task of the phase R2.

\begin{tabular}{ll}
\hline \multicolumn{1}{c}{ Task Name } & \multicolumn{1}{c}{ Task Description } \\
\hline & $\begin{array}{l}\text { The first phase of the plan will design the first maintenance intervention to be } \\
\text { performed in the river in order to achieve the reversion of channel to a more } \\
\text { natural state will include the and cutting of the already present vegetation and } \\
\text { the removal of logs and debris inside the riverbed. Moreover, it must be } \\
\text { performed the assessments of river stability and morphological regime, the } \\
\text { prediction of erosion, deposition and sediment transport processes and rates, the } \\
\text { optimization of the location and the design of the structures in unstable rivers, } \\
\text { the design of the bank protection and river training works, the design of the } \\
\text { sesign of the first maintenance } \\
\text { intervention }\end{array}$ \\
\end{tabular}

The aim is to recreate a river system as close as possible to the native one and, at the same time, to start a planned process that will ensures the continuity of maintenance.

The design of the maintenance plan will focus on 3 different zones:

- $\quad 1$ st zone-the wetland area (next to the river), in which the only of the white willow tree (Salix alba). The presence of slender and flexible young individuals plays an important role in controlling erosion and increasing roughness, improving retention times. So, their presence is necessary to preserve the river functionality but, the maintenance plan has to be designed taking into account that the size of this essence have to be maintained in a defined range to avoid that too large size elements interfere

R2.2

Design of the maintenance plan

The main objective in maintaining this area is to ensure the normal flow of ' water while opposing the river banks erosion.

- $\quad$ 2nd zone-the banks, there are several hygrophilous tree species. In this case, the main function of the vegetation is the ecological corridor for the wildlife movement and shelter.

- $\quad 3$ rd zone-state property between the river and the cultivated land. In this area, it must be planted a range of tree species of flood plains with the function of making the ecological and the landscape improvement as well as the energetic aspect.

The results of this task will be a scheme for the cuttings and seedlings positioning.

This task includes the design of the forest site and the definition of the

R2.3 agricultural and forestry machinery needed for performing the maintenance tasks (chain saws, winches, cable cars, bobcat with forestry pliers, forestry excavator with processor, telescopic loaders, wagons for timber transportation, etc.).

Design of the forest site

The track will be created between the $2^{\circ}$ and $3^{\circ}$ zone and the in this task it will be defined how to implement the maintenance track for allowing the machine to enter in the river and to stack the residual biomass with a dual objective: allowing scheduled maintenance operations (that at regime will be performed not more than once in a year) and creating a walking/bicycle path. The parameter that will be defined in this phase are related to the track dimensions, the number and type of machines that will be needed in the implementation phase.

R2.4

Design of the Forest Service Trail that will be used also a walking/bicycle path

\subsection{Phase R3. Design of Energy Production and Distribution Plant}

Scope of the proposed phase is the design of a small-scale mobile power production unit for energy production from biomass residues generated from the maintenance of a defined stretch of river, integrated with green waste generated by the maintenance of public demesne areas (roads and rails borders, small waterways, public parks, and forest). This versatile unit will enable operation close to the place of feedstock origin, minimizing transportation and logistics costs. The technology in which the phase will focus consists of a gasification reactor combined with an internal combustion engine for electrical power and heat production, achieving high energy and environmental performance. In order to define the most suitable system, the tasks described in Table 3 must be implemented. 
Table 3. Task of the phase R3.

\begin{tabular}{|c|c|}
\hline Name Task & Task Description \\
\hline $\begin{array}{l}\text { R3.1 } \\
\text { Evaluation and identification } \\
\text { of the best available conversion } \\
\text { technology }\end{array}$ & $\begin{array}{l}\text { The most suitable typology of gasification plant, based on available biomasses } \\
\text { quantities and characteristics must be identified. } \\
\text { A comparison of features, costs (of implementation and maintenance), } \\
\text { maintenance needed, will be performed. } \\
\text { The parameters that will be taken into account to compare the different options } \\
\text { are: maximum proven commercial capacity }\left(\mathrm{kW}_{\mathrm{el}}\right) \text {, start-up time (min), } \\
\left.\text { sensitivity to fuel characteristics, tar production full load (g/ } \mathrm{NM}^{3} \mathrm{gas}\right) \text {, size and } \\
\text { volume gas cleaning section, quantity residual tars, sensitivity to load } \\
\text { fluctuations, turn down ratio, cold gas heating value full load }\left(\mathrm{MJ} / \mathrm{Nm}^{3}\right) \text {, specific } \\
\text { consumption of biomass (Kg/h and tons/year), guaranteed annual working } \\
\text { hours (h/year), humidity value of biomass entering the system and relative plant } \\
\text { productivity }(\%) \text {. }\end{array}$ \\
\hline
\end{tabular}

R3.2

Design of the district heating and of the power distribution connection
The objective of this task is to design heating net that from the plant will brought the heat produced by the gasification process to the selected energy users; this include pipes sizing for the heating transportation and calculation of heating loss. One or more buildings will be selected for implementing the energy plant. The choice should take into account the availability of space to install the plant for the generation of electricity, heating and cooling.

It must be defined the supply chain design with the identification of biomass suppliers, the biomass storage site in relation with the plant site and electrical and thermal energy users involved.

All the available sites for the installation of the storage area must be evaluated taking into account the main phases from the collection to use of biomass: geographical distribution and quantities of biomass in the selected area (as defined in Phase R1), collection procedures, transportation and storage, preparatory treatments and valorization, energetic conversion method, process waste disposal, position of selected energy users. The objective of the analysis will be the minimization of the transportation costs and environmental impact and the optimization of use of energy produced.

The analysis will integrate the results of phase R2, in which the first element of the residual biomass supply chain will be designed (skidding and stacking of biomass deriving from the river maintenance).

The design of the logistic chain must start from the biomass transportation from the river bank to the storage site that will be structured taking into account:

Evaluation and planning of logistic aspects related to the plant installation
- the average and peak amount of residual biomass to store (considering also waste coming from private green maintenance companies and the possibility of future agreements with other local);

- the feedstock preparation phase. Preparation is in fact required for almost all types of biomass materials because of large variety in physical, chemical and morphological characteristics;

- the pretreatment processes. Since the fuel characteristics can be influenced by pretreatment process of biomass, it will be necessary to design the following systems:

- $\quad$ sizing in order to obtain the size range suitable for the selected gasifier type. Sizing of the feedstock may be necessary as different sizes are specified for different types of gasifiers.

- drying is advisable if fresh wet materials (moisture content $50-60 \%$ on wet basis) are to be gasified.

\subsection{Phase R4. Economic and Environmental Impact Analysis}

The development of bioenergy projects is driven by a greening of the energy sector. The environmental sustainability of biomass production, logistics, and the conversion chain therefore needs to be secured by application of sustainability criteria as presented in the Renewable Energy Directive (RED) and particularly the communication (COM2010(11)) "on sustainability requirements for the use of solid and gaseous biomass sources in electricity, heating and cooling". In addition, relevant voluntary sustainability criteria can be found in certification systems like FSC, PEFC, the Dutch NTA8080, the German ISCC (International Sustainability and Carbon Certification), etc., can be 
considered. Nevertheless, the environmental sustainability is not the only factor that has to be taken into account in the decision of implementing a green energy production system; either a public or private investor has also to evaluate the economic aspects.

The aim of this phase is to provide a tool for the evaluation of the project feasibility and convenience from both an economical and environmental point of view. It will be implemented at the end of phase R3 after the cogeneration plant selection and design. The software will allow us to combine together the economical and the environmental analysis.

The carbon balance and energy efficiency of a biomass project will be obtained by performing an LCA (Life Cycle Assessment) analysis with on the type and amount of residues used, transport distance, energy efficiency of the conversion technology etc., thereby following the "Methodology for calculating greenhouse gas performance of solid and gaseous biomass used in electricity, heating and cooling" as presented in Annex 1 of COM2010.

A GIS-based algorithm will be developed in the form of a standalone executable, independent from any specific GIS environment, working as a black box on input data and producing output results as data and maps. The inputs of the algorithm are

- a layer representing the potential locations where a biomass to energy conversion plant could be installed based on the set of data described above;

- three layers representing biomass productivity, production costs and corresponding energy content;

- a layer pointing out the transport network of the area under analysis;

- data regarding transport costs and transport related emissions;

- data regarding power plant characteristics.

For the selected location under study, the algorithm will compute the marginal cost of the biomass delivered from the production location to the plant, and the emissions associated to the biomass transport; the outputs of the algorithm are georeferenced raster or vector maps and data results, post-processable through the use of any common GIS environment.

The main functionalities of the software will be the following:

- the possibility to select and to navigate digital maps of the area/region of interest and to apply constraints to the characteristics of the area under exam (industrial area, accessibility, supplies etc.) through a GIS based analysis. The digital maps already contain information about logistic infrastructures as well as main residential, industrial and commercial areas and characteristics;

- the possibility to identify within the selected area industrial zones or potential storage zones, together with an annual biomass productivity sufficient to feed a biomass to energy conversion plant;

- the possibility to identify and to add on selected digital maps information about existent or planned bioenergy users (residential districts, commercial/industrial districts, schools, hospitals, sport facilities, publics service buildings, etc.);

- the possibility to set collection and logistics management strategies (types, number, frequencies of vectors, routes constraints, unit cost for logistics, etc.) which will be required for the optimization of the transport path through the use of a shortest path algorithm;

- a calculation tool for evaluating economic (PBP, IRR, NPV) and environmental sustainability of simulated bioenergy plan according to previously defined parameters.

\subsection{Phase R5. Implementation of the Maintenance Plan on Selected River Stretch}

The whole cycle of requalification and maintenance of the interested site will be managed by the phase coordinator that will assign to a selected number of local farmers the task of performing the cleaning, cutting/trimming and the replanting of the river zones. In agreement with the regional forest 
nursery center, the farmer will prepare the cuttings and seedlings necessaries for replanting in alveolus. Only native species will be used. The phase will be carried out in two main tasks shown in Table 4.

Table 4. Task of the phase R5.

\begin{tabular}{ll}
\hline \multicolumn{1}{c}{ Name Task } & \multicolumn{1}{c}{ Description Task } \\
\hline & This task is related to the requalification of the selected river stretch in which \\
the following tasks will be performed: \\
- $\quad \begin{array}{l}\text { creation of the forest site and preparation of the relative machines as } \\
\text { R5.1 }\end{array}$ \\
$\begin{array}{l}\text { Requalification of the } \\
\text { selected river stretch }\end{array}$
\end{tabular}

The present task is related to the replanting of selected species:

- $\quad$ cuttings and seedlings preparation;

R5.2

Replanting of selected species
- identifying the seedlings position (following the guidelines defined in phase R2);

- $\quad$ lying down a biodegradable mulching sheet in order to contain the natural vegetation;

- $\quad$ planting the selected species.

\subsection{Phase R6. Realization of Energy Plant for Energy Production and Distribution}

Following the results of the phase R3, this phase provides the installation of the plant prototype in the relative site.

This phase will implement the system and all its component as designed in R3. The first task that will have to be performed is related to the preparation, in structural terms, of the site in which the plant will be installed by building all the necessary structures (concrete platform to support the plant, system coverage, etc.). The plant site and the storage area with the appropriate structures will have to be prepared together with the area for biomass preparation and pretreatments.

After the site and all the relative structures and equipment are in place, it will be possible to proceed with the installation of the energy generation system and of all its components (e.g., the gasifier system coupled with diesel engines or gas turbine, the biomass hopper, etc.).

The following tasks will be performed:

$>\quad$ preparation of site for plant installation (building of infrastructures and structures needed);

$>\quad$ preparation of site for biomass storage, preparation (selection and sizing) and treatments (drying);

$>$ supplying of needed equipment for biomass preparation and treatment;

$>$ installation of plant;

$>$ installation of the heating net;

$>$ link to the electrical grid;

$>\quad$ definition of land grant agreement between farmers that will be in charge of river and small waterways maintenance and residual biomass exploitation, and public bodies responsible for the selected areas management;

$>\quad$ definition of contractual agreements and delivering modality between energy plant manager and public and private company in charge of public green maintenance.

\subsection{Phase R7. Plant Operation and Performances Evaluation}

The objectives of this phase are the testing, approval, and certification of the proposed gasifier systems for the application of interest. The development of Test Procedures and Methodology as well as the formulation of acceptable performance levels will be performed. 
The long-term acceptability of the gasifier technology and the extent of penetration in the market depend on the performance of the gasifier and also on the gas cleanup systems, the end use devices and the range of fuel tolerance (both type and size). There is a need for a safe, reliable, environmentally conforming, and economically viable system available to a properly trained user through a carefully screened user training program. It is in the interest of the user as well as the supplier that the gasifier systems be properly tested and effectively combined to deliver expected performance.

This phase will lay down the minimum requirements for the system to follow; a working manual will be provided in which the codes and standards, system specifications, operating and maintenance procedures, performance guarantees, list of items supplied, and user site layout requirements will be reported for safety for the system supplied to him. This document also details the qualifying and acceptable performance levels and testing and performance evaluation procedures for biomass gasifiers and gasifier-engine systems.

Several parameters will be evaluated, such as the gasification efficiency, the maximum permissible levels of tar content of gas, the particulate content of gas, the total tar and particulate (TTP), the duration sustainable for uninterrupted continuous operation, the conservation/consumption, overall system efficiency at rated load, the engine exhaust emissions, and the availability of the system during the testing schedule.

A document containing all the information on the system performance and test results will be edited at the end of the phase. The document will contains the testing procedure for qualifying, testing and performance evaluation of the gasifier spark ignition producer-gas engine system and different information on the system (gasifier type, tested capacity, starting system, starting time, biomass requirement, gas output rate, average composition of gas, calorific value of gas produced, gasification efficiency at rated output, gasification efficiency at minimum load, hopper capacity, longest duration for which the gasifier system can be operated continuously, type of biomass re-filling (manual or mechanized), time spent per refill of hopper, frequency of biomass re-filling, type of ash disposal (dry water seal/wet), tar and particulate contents of gas before and after the cleaner-cooler, manpower requirement) and description of any other necessaries procedures/precautions or checks.

\subsection{Model Application to an Existing Site}

The application of the new virtuous model to an existing site located around a river characterized by a very poor state of preservation is presented below.

In particular, this new approach of conservative and multifunctional management can be experimented on the Musone River (Marche, Italy), a river identified by an important flood event in March 2011, that lead to damages for a total of 480 million Euros and resulting in two deaths. More specifically, the area covered by the model is located between the towns of Castelfidardo and Recanati, about $10 \mathrm{~km}$ from the river outlet. It analyzes a stretch of $4 \mathrm{~km}$ between the bridge site on Ricciola locality and the industrial zone Squartabue, represented in Figure 2.

In fact, the Musone River is currently in a very poor state of preservation, with a significant degradation and impoverishment of the native vegetation. The planning of the whole maintenance and requalification project will be based on the analysis of the territory and its different functional aspects such as: the potential vegetation and its functionalities, and the possibility of implementing a suitable mechanized forestry maintenance system. River maintenance covers cutting of vegetation, dredging, bank and tree clearance, and repairs to banks and structures. These activities influence all aspects of river management including flood defense, morphology, conservation, recreation and fisheries, and it involves the application of a large number of regulations and the interaction of different authorities, often difficult to integrate and unify.

To assess the feasibility of such a model, it is necessary to evaluate different aspects and characteristics of the territory of interest and to elaborate an exhaustive picture of the entire ecosystem presents, including its potentialities from an energetic point of view. 


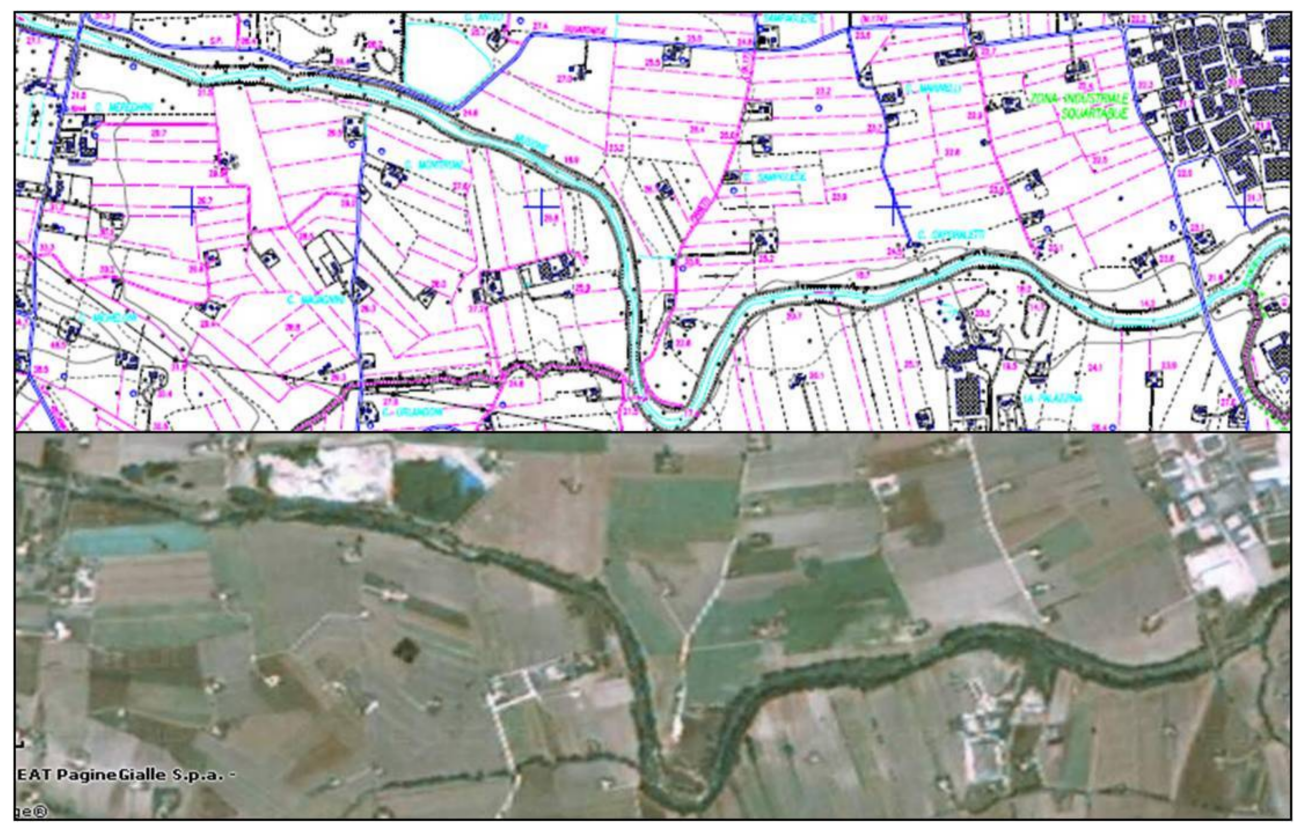

Figure 2. Picture and map of the investigated area.

The scope of the proposed action is the design of a small-scale mobile power production unit for energy production from biomass residues generated from the maintenance of a defined stretch of the Musone River, integrated with green waste generated by the maintenance of public demesne areas (roads and rails borders, small waterways, public parks, and forest). This versatile unit will enable the operation close to the place of feedstock origin, minimizing transportation and logistics costs. The technology in which the action will focus consists of a gasification reactor combined with an internal combustion engine for electrical power and heat production, achieving high energy and environmental performance.

A thermal central powered by wood chips is installed on land owned by a local farm located near the Musone River, in the area between the industrial area of Castelfidardo and the municipality of Recanati (as shown in Figure 3). The biomass obtained from the ordinary watercourse maintenance is used to feed the thermal plant. The electricity is fed into the network, while the thermal energy is partly sold to neighboring companies and partly serves to heat the greenhouse of the farm itself.

The vegetation is ceded according to forest management plans, which are diversified for the different tree types present on the riverbed.

The various problems of finding biomass for energy production, especially the valley part of the Marche region (given the absence of wooded areas), the current state of degradation of the river and the possibility of having a constant supply of wood were the main reasons for identifying the Musone River as a potential biomass supply area.

The underlying problem is that, up to now, no effective and continuous management of the river has been planned to keep the river in a good state of conservation. In fact, the natural evolution of vegetation can lead to the presence of senescent trees or in poor health conditions of the riverbed, putting the natural flow of water at risk.

Therefore, a hypothesis of management of the investigate area is analyzed in order to understand if it can generate environmental benefits without neglecting the economic aspect. If the results of this new management are positive, it is obvious that this methodology can be applied to the entire river and, with some measures, also to minor watercourses. 


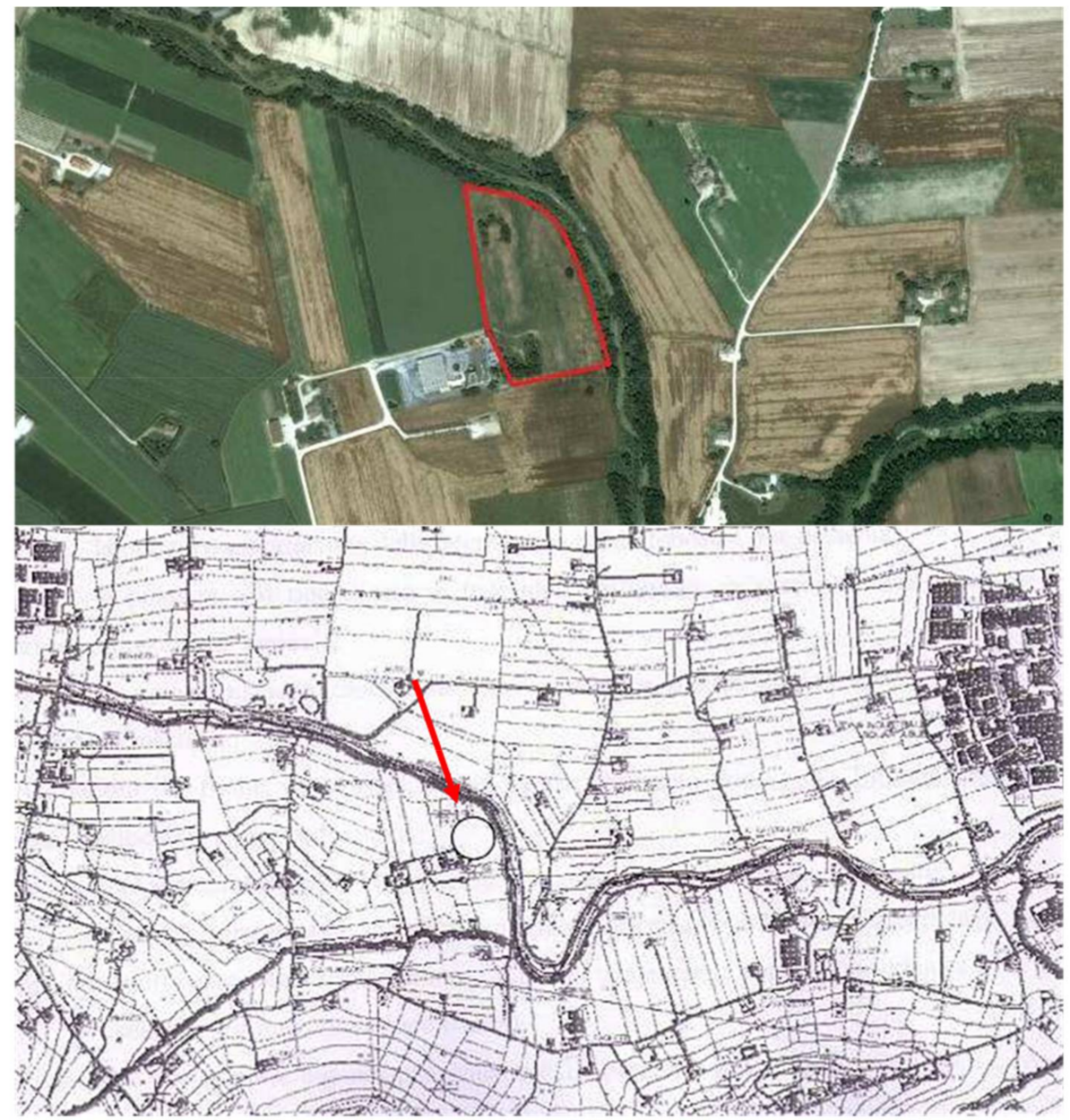

Figure 3. Location of the farm along the Musone River.

The project is based on the integration of the following objectives:

- regulation of watercourses, by maintaining the drainage network and hydraulic functions;

- ecological, landscape and fruition improvement of natural environments;

- creation of synergies between public entities interested in the land management and private entities such as agricultural companies;

- economic sustainability of the entire process, in order to ensure management continuity;

- transition from the current "emergency management" approach to one of "prevention and intervention planning".

Therefore, the energy locally produced provides opportunities for socio-economic development for rural populations and contributes to a more active and sustainable management of agroforestry resources.

The model implemented in the area individuated near the Musone River is summarized in Figure 4. As starting point, the river maintenance is taken into account. First of all, the modeling actions of the riverbed must be identified. 


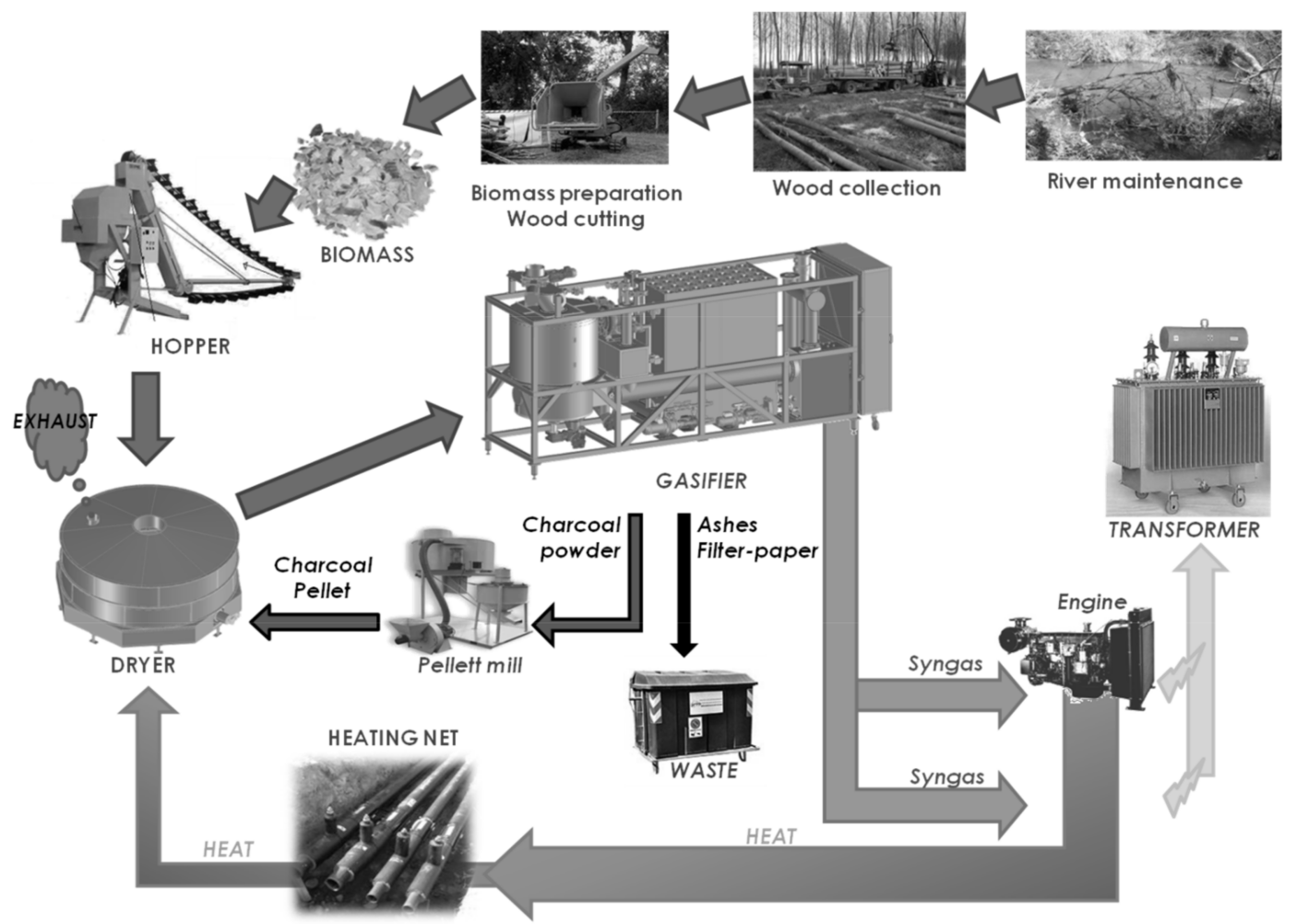

Figure 4. General scheme of the model.

The main important modeling action individuated for the investigated river is the restoration of the riverbed sections. The restoration of the sections of the riverbed means the removal of excess earthy material present on the river bed and the remodeling of the banks so that the internal area of the riverbed meets the maximum flow rate that would occur following extraordinary rainy events. The sizing of the reservoir is developed considering a rain of extraordinary entities with a return time of 200 years. At the level elevation that would reach the river in these conditions, $1 \mathrm{~m}$ of height is added as a security factor.

The ideal shape that the river assumes (Figure 5) is that of double inverted trapezium where the smaller one is in the center and in a lower position (riverbed of lean) and the larger one is at an upper height and serves to contain the water in full conditions and therefore it is submerged only at certain times of the year.

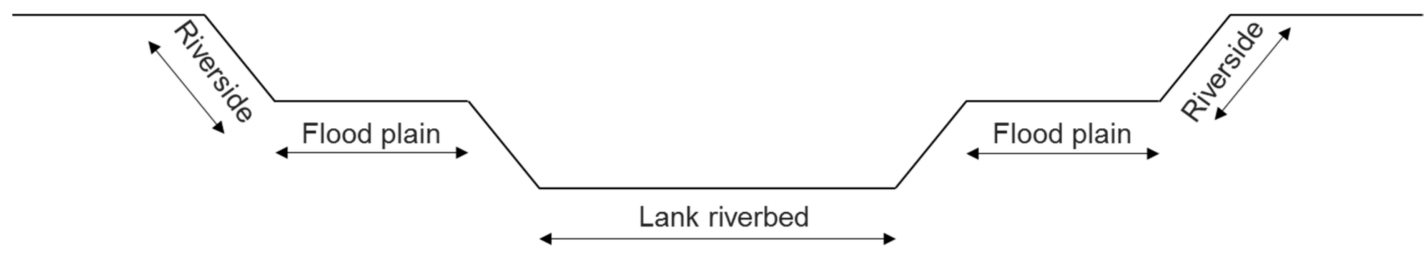

Figure 5. Ideal section of the river.

The ideal section of the river is about $25 \mathrm{~m}$ wide (length of the upper trapezium base); this means that if the riverbed extends for about $7 \mathrm{~m}$ at the center of the fluvial pole (where the constant flow of water is assured), on the sides there are two floodplains of $9 \mathrm{~m}$ each. The reshaping operation is considered to be carried out with the method already well established up to now by means of large power excavators. 
In order to implement the river maintenance, the floodplains are considered to be subject to planting of dedicated tree crops, i.e., tree plantations not subject to forestry constraints such as Short Rotation Forestry (SRF) and Medium Rotation Forestry (MRF). The dedicated tree crops are born with the objective of producing biomass for energy purposes and are therefore varieties of fast-growing species [17]. The MRF has a plant density of around 1000 to 1800 plants and rotational shifts of 6.7 years. In the present study, the planting of white willow (Salix Alba) in the floodplains is considered by opting for medium-long rotations of the MRF type. Once the planting has been carried out, cultivation operations such as weeding, fertilizing, and irrigation are not carried out, with the exception, however, of shredding the grass in the row before harvesting.

Obviously, older arboreal individuals have less elasticity than those that are cut more frequently and may therefore create an obstacle to water flow. To counteract this inertia, in the middle of the cycle (i.e., after about three years) all the primary branches are removed up to a height of about $2 \mathrm{~m}$. This operation eliminates all the ramifications at the base of the trunk because otherwise, once submerged by water, they could trap plastic bags, branches, and anything else carried by the current.

Two methods are used for harvesting operations: a rubberized bobcat equipped with forest grippers and a tractor with a trailer equipped with a forestry crane. The bobcat performs the felling and bundling, and in the meantime, the material on the trailer is loaded with the crane. Once the load is complete, the biomass is brought to the storage site.

The removal operation of the branches requires a chainsaw with which to cut the branches on the shaft up to the desired height. It is important to provide descent ramps to allow vehicles to enter the floodplain area. For the investigated scenario, it was decided to use specially designed wheeled and relatively light means for maintenance operations to create as little disturbance as possible to the riverbed. The best time to perform the intervention is the summer period as it is the least rainy; the river level is at the annual low and in the floodplain areas there is a relatively dry ground.

It was already said that the ideal section of the river is about $25 \mathrm{~m}$ and this means that if the riverbed extends for about $7 \mathrm{~m}$ at the center of the fluvial pole (where the constant flow of water is assured), on the sides there are two floodplains of $9 \mathrm{~m}$ each. The expected planting pattern is $2.5 \mathrm{~m}$ between rows and at intervals of $2 \mathrm{~m}$ within the row, with a density of 2000 plants per hectare.

Assuming a forestry site for the management of these areas, it is considered an interruption of the rows every $250 \mathrm{~m}$ to allow the crossing of the forest means in the middle of the crop. The transverse passage is $6 \mathrm{~m}$ wide and allows entry into the riverbed without having to travel long and boring distances. If this space not planted is considered on the total available surface, the plant density is reduced to 1952 plants per hectare.

Knowing that the ideal width of each floodplain is $9 \mathrm{~m}$ and a single row occupies the width of $2.5 \mathrm{~m}$, it means that on each side of the stream, it is possible to put three rows, and therefore, in the entire floodplain area, six rows are present. Therefore, considering the average production per tree with a six-year turn equal to $100 \mathrm{~kg}$, which corresponds to about $16.6 \mathrm{~kg}$ of fresh biomass per year per plant, it is possible to calculate that a total of 32.5 metric tonnes per hectare per year of biomass is obtained from the entire floodplain area; the same productivity value expressed on the river rod length is 48.8 metric tonnes per linear kilometer per year.

Once the maintenance management has been designed, the organization of the wood-energy supply chain must be defined. This step consists of the following four tasks:

- fuel preparation;

- biomass power plant design and management;

- rotation shifts of the dedicated tree crops;

- $\quad$ exploitation of the produced energy.

\subsubsection{Fuel Preparation}

The procurement of the agroforestry residue is divided into the following operations [18]. 
- abatement: cutting of the stem to the foot and landing;

- cutting of branches and cage until complete cleaning of the trunk and de-shaping;

- concentration: wood transport from the fall bed to the outskirts;

- transport: timber handling through forest and/or public roads;

- transformation: fuel reduction to practice sizes for common use (cut, slit, chipping).

\subsubsection{Biomass Power Plant Design and Management}

This phase is probably the most complex one of the energy supply chain. The characteristics that biomass must have are according to the type of plant to be fed.

In the present study, as biomass cogenerator, it was chosen a cogeneration system studied by some of the authors in a previous work [11]. This system is based on the gasification of wood biomass and a Stirling engine for the combined production of heat and power (CHP). It has an output of $100 \mathrm{~kW}_{\mathrm{e}}$ and $200 \mathrm{~kW}_{\mathrm{t}}$. The cogeneration system chosen is a commercial system and its main important characteristics are reported in Table 5 . In the previous study, this cogeneration system was chosen compared to others because, besides having a good global efficiency $(78.2 \%)$ and a low specific biomass consumption $(1.1 \mathrm{~kg} / \mathrm{hWh}$ ), it also ensures easy installation and operation. This small-scale (e.g., $150 \mathrm{~kW}_{\mathrm{e}}, 200 \mathrm{~kW}_{\mathrm{t}}$ ) gasification plant has been individuated as the best solution to exploit the residual biomass obtained from the Musone river maintenance, integrated by biomass from the near small waterway of "Fosso Rigo" and from public demesnes green areas.

Table 5. Technical characteristics of the cogeneration system chosen.

\begin{tabular}{ll}
\hline Nominal electric power $(\mathrm{Pe}, \mathrm{nom})\left[\mathrm{kW}_{\mathrm{e}}\right]$ & 100 \\
Net electric power produced $\left[\mathrm{kW}_{\mathrm{e}}\right]$ & - \\
Electric power absorbed $\left[\mathrm{kW}_{\mathrm{e}}\right]$ & - \\
Thermal power $\left[\mathrm{kW}_{\mathrm{t}}\right]$ & 200 \\
Biomass consumption $(\mathrm{Cbiom})[\mathrm{t} /$ year] & 880 \\
Guaranteed hours of plant operation $[\mathrm{h} /$ year] & 8000 \\
Annual production of electricity $[\mathrm{kWh} /$ year] & 800,000 \\
Biomass humidity $(\%)$ & $\mathrm{Max} 40 \%$ \\
Calorific value of wood chips $(\mathrm{Pc}$, biom $)[\mathrm{kcal} / \mathrm{kg}]$ & 3000 \\
Calorific value of produced syngas $(\mathrm{Pc}, \mathrm{syn})\left[\mathrm{kcal} / \mathrm{Nm}^{3}\right]$ & - \\
Volume of produced syngas $(\mathrm{Vsyn})[\mathrm{Nm} / / \mathrm{h}]$ & - \\
Specific biomass consumption $[\mathrm{kg} / \mathrm{kWh}]$ & 1,1 \\
Gasification efficiency $(\%)$ & - \\
CHP report $[\mathrm{kWh} / \mathrm{kWh}$ ] & 2 \\
Total thermal energy introduced $(\mathrm{kcal} / \mathrm{h})$ & 330,000 \\
Heat converted into thermal energy $(\mathrm{kcal} / \mathrm{h})$ & 172,000 \\
Total energy exploited $(\mathrm{kcal} / \mathrm{h})$ & 258,000 \\
Total efficiency $(\%)$ & 78.2 \\
Material type & Wood chips G50 \\
\hline
\end{tabular}

Figure 6 shows a scheme of the position of the plant inside the storage site.

Let us determine the energy needs of the plant. The biomass consumption is 880 ton/year at $40 \%$ humidity. Fresh biomass (freshly felled tree) is considered to have a moisture content of $50 \%$. The energy requirement of the system is therefore equal to $978 \mathrm{ton} /$ year. 


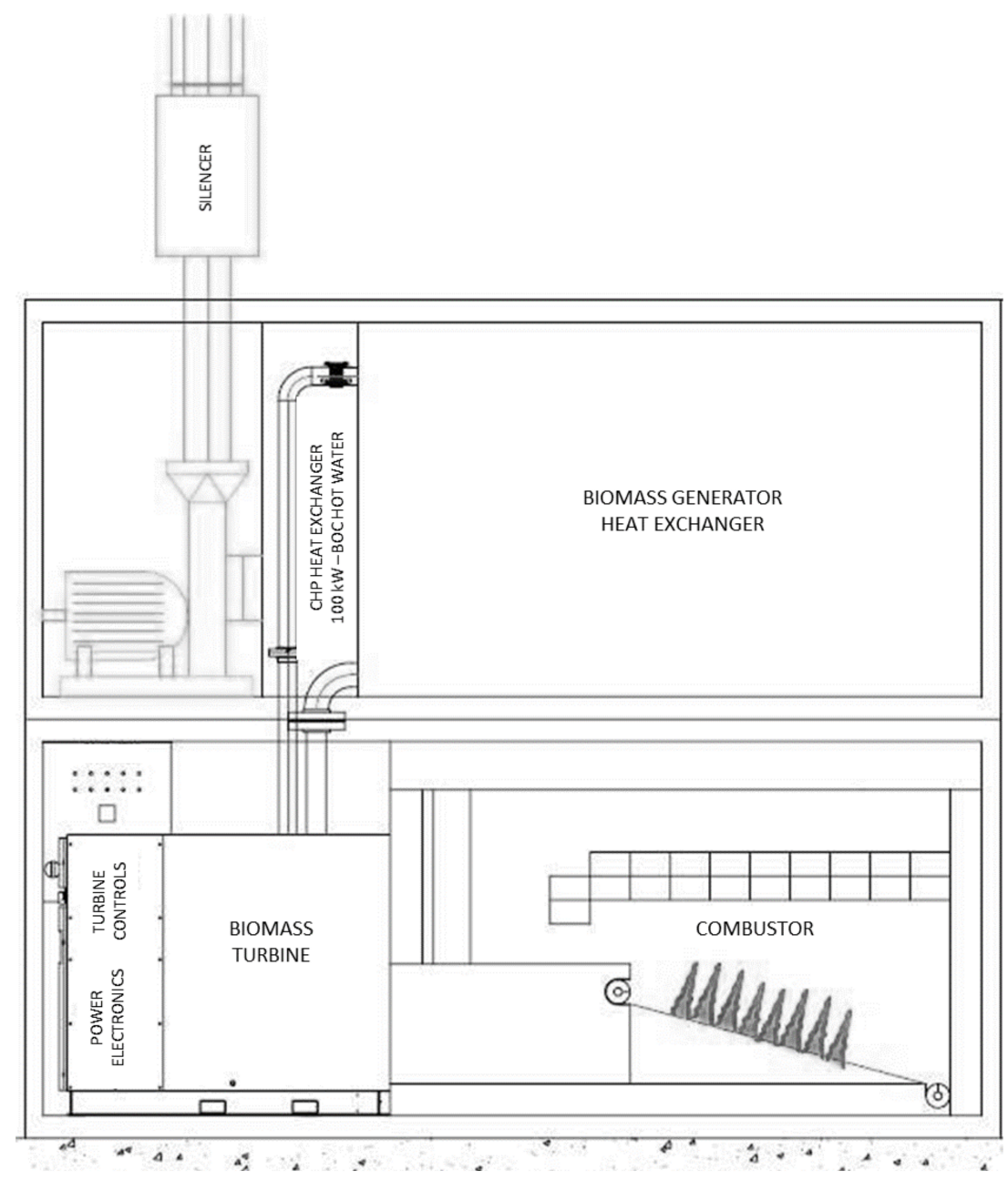

Figure 6. Central cogeneration positioning scheme.

\subsubsection{Rotation Shifts of the Dedicated Tree Crops}

Once the productivity of the tree crops and the energy needs of the cogeneration plant are determined, it is possible to calculate the surfaces involved and the MRF rotation cycles.

By considering that the energy requirement of the plant is 978 ton/year of fresh biomass, the production of MRF is equal to $48.8 \mathrm{ton} /$ year linear $\mathrm{km}$ and the planting pattern described above, it is possible to calculate that a river length of $3.33 \mathrm{~km} /$ year will have to be managed annually, considering that the turn between two successive cuts in the same lot is 6 years.

\subsubsection{Exploitation of the Produced Energy}

The wood chips supply chain must have a local action. In fact, the distance between the place of collection and the use of biomass should be around $20-30 \mathrm{~km}$. This because this type of fuel shows a low energy content per unit of volume, and therefore, transport costs greatly affect the final cost of the material.

All produced electricity will be sold, with the exception of the part necessary for the self-sufficiency of the plant. Its valorization follows the mechanism of all-inclusive tariffs recognized by the Italian GSE (Gestore Servizi Energetici) to producers of electricity from renewable sources. The resulting incentive has a duration of 15 years from the start of the plant and amounts to $0.28 € / \mathrm{kWh}_{\mathrm{e}}$ (typical Italian market value).

From the thermal point of view, two scenarios can be considered: a part of the thermal energy is self-consumed within the farm and the other is sold to external users. 
It is possible to assume to heat a greenhouse for the vegetables production located inside the farm with a part of the heat produced in order to anticipate the productions leading in this way to a higher price of the vegetable in the market. The calculation of the heat requirement of the greenhouse is rather complex due to the number of variables involved; for this reason, a simplified common equation (Equation (1)) can be used.

$$
Q=K_{r} \cdot S \cdot\left(T_{i}-T_{e}\right)
$$

where $Q$ is the greenhouse heat requirement $(\mathrm{kcal} / \mathrm{h}), K_{r}$ is the global heat transfer coefficient $\left(\mathrm{kcal} /\left(\mathrm{hm}^{2} \cdot{ }^{\circ} \mathrm{C}\right)\right), S\left(\mathrm{~m}^{2}\right)$ is the total external area, $T_{i}\left({ }^{\circ} \mathrm{C}\right)$ is the desired indoor temperature of the greenhouse and $T_{e}\left({ }^{\circ} \mathrm{C}\right)$ is the external temperature.

The limits of Equation (1) lie in the fact that not all possible sources of dispersion are considered. However, this is acceptable if the data calculated in this way is used to size the greenhouse heating system; in this case, in fact, the sizing is carried out assuming the most conservative conditions. The losses due to irradiation, which are not negligible, can instead be included in the $K_{r}$ coefficient because they are variable according to the covering material.

In the present study, a typical commercial regular pavilion greenhouse is considered (shown in Figure 7). Assuming all the technical parameters reported in Table 6, a heat requirement equal to $54311 \mathrm{kcal} / \mathrm{h}$ can be calculated for the greenhouse considered.

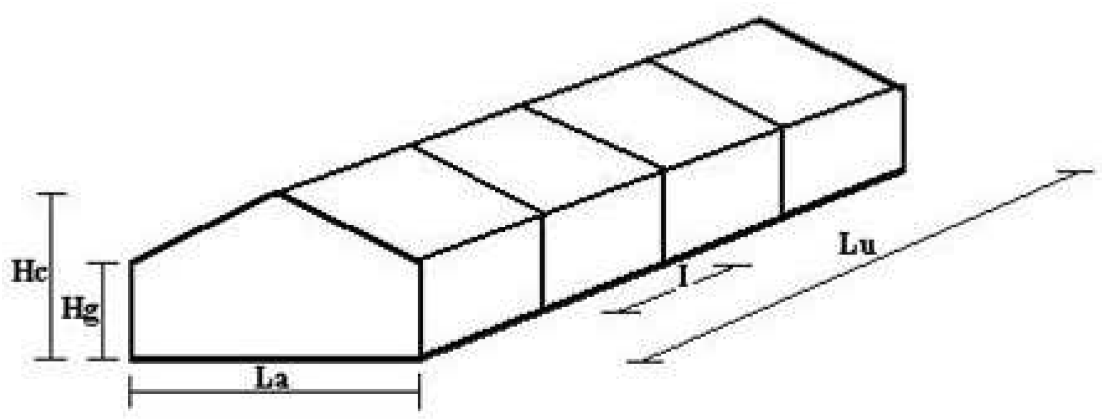

Figure 7. Regular pavilion greenhouse.

Table 6. Greenhouse heat requirement calculation.

\begin{tabular}{ccc}
\hline Parameter & Unit & Value \\
\hline $\mathrm{La}$ & $\mathrm{m}$ & 10 \\
$\mathrm{Lu}$ & $\mathrm{m}$ & 30 \\
$\mathrm{l}$ & $\mathrm{m}$ & 3 \\
$\mathrm{Hc}$ & $\mathrm{m}$ & 4.5 \\
$\mathrm{Hg}$ & $\mathrm{m}$ & 2.5 \\
$\mathrm{Kr}$ & $\mathrm{kcal} /\left(\mathrm{hm}^{2} \cdot{ }^{\circ} \mathrm{C}\right)$ & 5 \\
$\mathrm{~S}$ & $\mathrm{~m}^{2}$ & 543 \\
$\mathrm{Ti}$ & ${ }^{\circ} \mathrm{C}$ & 18 \\
$\mathrm{Te}$ & ${ }^{\circ} \mathrm{C}$ & -2 \\
$\mathrm{Q}$ & $\mathrm{kcal} / \mathrm{h}$ & 54,311 \\
\hline
\end{tabular}

The remaining part of the heat is instead sold to external users and can be quantified in $0.025 € / \mathrm{kWh}_{\mathrm{t}}$ (typical Italian market value).

\subsubsection{Economic Feasibility}

Let us evaluate the economic aspects deriving from the implementation of the agro-energy model developed for integrating the maintenance of the Musone river with the energy production from the biomass through the cogeneration plant selected. Table 7 reports the revenues deriving from the sale 
of electricity and thermal energy plus the savings deriving from the use of biomass for heating the company's greenhouse instead the exploitation of traditional fuels

Table 7. Revenues from electricity and thermal energy.

\begin{tabular}{|c|c|c|}
\hline Plant Characteristics & & \\
\hline Electric power produced & 100 & $\mathrm{~kW}_{\mathrm{e}}$ \\
\hline Hours of annual operation & 8000 & $\mathrm{~h}$ \\
\hline \multicolumn{3}{|l|}{ Sale/use of electricity } \\
\hline Produced $k W h_{e}$ & 800,000 & $\mathrm{kWh}_{\mathrm{e}} /$ year \\
\hline Self-consumed energy & 0 & $\%$ \\
\hline Energy delivered to the network & 100 & $\%$ \\
\hline All-inclusive rate (1-15 years) & 0.28 & $€ / \mathrm{kWh}_{\mathrm{e}}$ \\
\hline Total revenue from generated electricity & 224,000 & $€ /$ year \\
\hline \multicolumn{3}{|l|}{ Sale/use of thermal energy } \\
\hline Cogeneration ratio & 2 & $\mathrm{kWh}_{\mathrm{t}} / \mathrm{kWh}_{\mathrm{e}}$ \\
\hline Thermal power available & 200 & $\mathrm{~kW}_{\mathrm{t}}$ \\
\hline Produced $\mathrm{kWh}_{\mathrm{t}}$ & $1,600,000$ & $\mathrm{kWh}_{\mathrm{t}} /$ year \\
\hline Produced kcal & $1,376,000,000$ & $\mathrm{kcal} /$ year \\
\hline \multicolumn{3}{|l|}{ A-Replacement of existing heating system } \\
\hline$\%$ of utilization & 15 & $\%$ \\
\hline Used $\mathrm{kWh}_{\mathrm{t}}$ & 234,169 & $\mathrm{kWh}_{\mathrm{t}} /$ year \\
\hline Greenhouse heat requirement & 54,311 & $\mathrm{kcal} / \mathrm{h}$ \\
\hline Heating hours in winter & & $\mathrm{h}$ \\
\hline Lower calorific value of Diesel fuel & 10,200 & $\mathrm{kcal} / \mathrm{kg}$ \\
\hline Efficiency of diesel heating system & 85 & $\%$ \\
\hline Revenue from thermal energy saved & 17,907 & $€ /$ year \\
\hline \multicolumn{3}{|l|}{ B-Sale of thermal energy } \\
\hline$\%$ of utilization & 85 & $\%$ \\
\hline Thermal energy salable & $1,365,831$ & $\mathrm{kWh}_{\mathrm{t}} /$ year \\
\hline Thermal energy value & 0.025 & $€ / \mathrm{kWh}_{\mathrm{t}}$ \\
\hline Revenue from sale of thermal & 34,146 & $€ /$ year \\
\hline Total revenue thermal enegy saved/sold & 52,053 & $€ /$ year \\
\hline Total revenue from electricity and thermal energy & 276,053 & $€ /$ year \\
\hline
\end{tabular}

It is important to point out that the contribution deriving from thermal energy is much lower than that linked to the sale of electricity; for this reason, in the present work, it was chosen to opt for the construction of a cogeneration plant and not a simple biomass boiler.

As specified also by Giacchetta et al. [11], beyond its technical performance, no engineering project can be considered desirable if it is not accompanied by a solid financial sustainability. For this reason, an evaluation of the main important investment parameters has been here carried out for the implementation of the model in the selected site.

Considering a total CAPEX (capital expenditure) of the plant equal to $€ 907,500$ (value calculated on the basis of a datasheet of the cogeneration system and a total cost of forestry and auxiliary works of $€ 260,500$ ) and an OPEX equal to $26,080 €$ /year, a tax rate of $5.50 \%$ and a bank loan duration of 15 years, it is possible to calculate a Net Present Value (NPV) equal to $€ 489,412.2$, a Pay Back Period (period for the return on investment) of seven years and an Internal Rate of Return (IRR) of 18.69\% (almost precautionary).

\section{Conclusions and Future Developments}

A sustainable agro-energy model for integrating the maintenance of rivers with the energy production from residual biomass was developed. 
The main innovation of this model consists in transforming a resource consuming activity, the territory maintenance, into a sustainable, profitable, and efficient one. The proposed model allows us to address, in an effective way, the following environmental, social, and economic problems and to integrate different needs, competences, and resources:

- a more efficient, constant, less invasive, and less costly maintenance of rivers;

- an environmental and economically sustainable maintenance of the territory;

- a reduction of floods consequences from the environment, the productivity activities, and the civil population;

- the creation of a synergy between local government and farmers that will be entitled of the river maintenance and recreating their connection with the territory;

- the production of green energy from biomass gasification;

- the reduction of green waste management costs for public administrations;

- the increasing usability of the territory from citizens with positive effects on rural tourism and on decreasing illegal dumping into rivers.

In Italy, a country that presents many areas characterized by elevated flooding risks a coherent policy for managing the river corridors maintenance does not yet exist. Usually, interventions are carried out sporadically and after emergencies. Extraordinary interventions are executed by companies specializing in the soil movement that enter in the watercourse with excavators and bulldozers and remove the herbaceous rind and the arboreal and shrub vegetation in a non-selective way. This kind of interventions trigger erosive phenomena, landslides, and the accumulation of debris inside the active river basin with the consequent occlusion of the sections.

The sustainable agro-energy model for integrating the maintenance of rivers with the energy production from residual biomass has been applied to an existing site characterized by a very poor state of preservation with significant degradation. It technical and economic feasibility were both demonstrated.

Acknowledgments: The authors wish to acknowledge Massimiliano Savoretti for the technical support given to this research work and for the data provided.

Author Contributions: Barbara Marchetti and Mariella Leporini conceived and designed the experiments; Barbara Marchetti, Mariella Leporini and Francesco Corvaro analyzed the data; Fabio Polonara coordinated the work.

Conflicts of Interest: The authors declare no conflict of interest.

\section{References}

1. Tabacchi, E.; Correll, D.L.; Hauer, R.; Pinay, G.; Planty-Tabacchi, A.-M.; Wissmar, R.C. Development, maintenance and role of riparian vegetation in the river landscape. Freshw. Biol. 1998, 40, 497-516. [CrossRef]

2. O'Connell, P.E.; Ewen, J.; O'Donnell, G.; Quinn, P. Is there a link between agricultural land-use management and flooding? Hydrol. Earth Syst. Sci. 2007, 11, 96-107. [CrossRef]

3. Brown, J.D.; Damery, S.L. Managing flood risk in the UK: Towards an integration of social and technical perspectives. Trans. Inst. Br. Geogr. 2002, 27, 412-426. [CrossRef]

4. Pedrazzi, S.; Allesina, G.; Morselli, N.; Puglia, M.; Barbieri, L.; Lancellotti, I.; Tartarini, P. The Energetic Recover of Biomass from River Maintenance: The REBAF Project. In Proceedings of the 25th European Biomass Conference and Exhibition, Stockholm, Sweden, 12-15 June 2017.

5. Brandoni, C.; Marchetti, B.; Ciriachi, C.; Polonara, F.; Leporini, M. The impact of renewable energy systems on local sustainability. Int. J. Product. Qual. Manag. 2016, 18. [CrossRef]

6. Van Leeuwen, E.S.; Vreeker, R.; Bruinsma, F.R. Integrated river basin project evaluation: A comparative study. Int. J. Environ. Technol. Manag. 2006, 6, 123-140. [CrossRef]

7. King, J.; Brown, C.; Sabet, H. A scenario-based holistic approach to environmental flow assessments for rivers. River Res. Appl. 2003, 19, 619-639. [CrossRef]

8. Kar, R.; Kar, R.K. Mangroves can check the wrath of tsunami. Curr. Sci. 2005, 88, 675. 
9. Myers, N.; Mittermeier, R.A.; Mittermeier, C.G.; Da Fonseca, G.A.B.; Kent, J. Biodiversity hotspots for conservation priorities. Nature 2000, 403, 853-858. [CrossRef] [PubMed]

10. Calder, I.R.; Aylward, B. Forests and floods: Moving to an evidence-based approach to watershed and integrated flood management. Water Int. 2006, 31, 87-99. [CrossRef]

11. Giacchetta, G.; Leporini, M.; Marchetti, B. Technical and economic analysis of different cogeneration systems for energy production from biomass. Int. J. Product. Qual. Manag. 2014, 13, 289-309. [CrossRef]

12. Bevilacqua, M.; Ciarapica, F.; Giacchetta, G.; Marchetti, B. Overview on the application of ISO/TS 16949:2009, in a worldwide leader company in the production of stainless steel tubes for automotive exhaust systems. Int. J. Product. Qual. Manag. 2011, 7, 410-439. [CrossRef]

13. Higano, Y.; Mizunoya, T.; Kobayashi, S.; Taguchi, K.; Sakurai, K. An International study on synthetic regional environmental policies for utilising biomass resources. J. Environ. Technol. Manag. 2009, 11, 102-117. [CrossRef]

14. Zhang, F.; Johnson, D.M.; Sutherland, J.W. A GIS-based method for identifying the optimal location for a facility to convert forest biomass to biofuel. Biomass Bioenergy 2011, 35, 3951-3961. [CrossRef]

15. De Montis, A.; Zoppi, C. Contingent Valuation of renewable energy innovations: Vegetal biomass in Italy. Int. J. Environ. Technol. Manag. 2009, 11, 218-233. [CrossRef]

16. Achterkamp, M.C.; Vos, J.F.J. A framework for making sense of sustainable innovation through stakeholder involvement. Int. J. Environ. Technol. Manag. 2006, 6, 525-538. [CrossRef]

17. Bacenetti, J.; González-García, S.; Mena, A.; Fiala, M. Life cycle assessment: An application to poplar for energy cultivated in Italy. J. Agric. Eng. 2012, 43, 72-78. [CrossRef]

18. Johnson, L.; Lippke, B.; Oneil, E. Modeling biomass collection and woods processing life-cycle analysis. For. Prod. J. 2012, 62, 258-272. [CrossRef]

(C) 2018 by the authors. Licensee MDPI, Basel, Switzerland. This article is an open access article distributed under the terms and conditions of the Creative Commons Attribution (CC BY) license (http:/ / creativecommons.org/licenses/by/4.0/). 